\title{
Tubular composite columns in a non-symmetrical fire
}

\author{
Markku Heinisuo; \\ Timo Jokinen, \\ Tampere University of Technology
}

\begin{abstract}
A considerable number of studies have been conducted worldwide on fires that act on all four sides of a column (symmetrical fire). These cases are used for the validation of the analysis models developed in this study. In real buildings the columns are often embedded.

If the fire does not act similarly on all surfaces of the column (non-symmetrical fire), it is extremely difficult to predict how the column will behave. The key research questions are: Is resistance stronger in non-symmetrical than in symmetrical fires? What is the final buckling mode, towards the fire or in the opposite direction?

Results of numerical analyses for reinforced concrete filled square steel tube columns in nonsymmetrical fires are presented for a total of 150 cases. An ISO 834 fire acts constant along the column on one, two adjacent or three sides. Three embedding systems are considered for the remaining sides: adiabatic, concrete wall and sandwich panel. The material models are done using the Eurocodes and an initial bow imperfection is considered. The reference cases are symmetrical cases.

When fire acted on one, two adjacent or three sides, the fire resistance times were on average about 3.4, 2 and 1.3 times longer than in a symmetrical fire. A concrete wall is a good thermal sink for columns. Slender columns typically buckle towards the fire. The final failure mode and corresponding resistance time depend on the direction of the initial bow imperfection. Experimental tests are needed to verify the results.
\end{abstract}

Key words: fire resistance; concrete filled steel tube column; non-symmetrical fire; finite element analysis; Eurocode

\section{Introduction}

\subsection{General}

Reinforced concrete filled tubular (CFT) columns have become popular among designers and structural engineers in recent years. These columns combine advantages of both steel and concrete materials, such as: attractive appearance, structural efficiency, fast construction technology and high fire resistance [1], [2].

Behavior of a CFT column in case of fire is more complex than at room temperature due to changes in material properties, which make it difficult to predict its failure. According to $[1,2]$, analytical methods developed in this field cannot predict behavior of CFT columns in fire, so numerical simulations are necessary. According to [2], most researches have adopted similar assumptions, all of which cannot be realistic representations of actual CFT column behavior. Both the effects of slip and air gap between the steel tube and the concrete core and the effect of concrete tension strength have been studied in [2], and the authors have concluded that they have only a minor effect on fire resistance time. They have also realized that initial deflection has some effect on fire resistance time, but it is acceptable to use the maximum value of the span/1000 [2].

A considerable number of numerical simulations and tests have been conducted worldwide on fire that affects all the four sides of a column. References [3-19] deal with steel tubes filled with plain concrete. References [20-28] deal with steel tubes filled with reinforced concrete. References [29-40] deal with steel tubes filled with fiber reinforced concrete. If fire acts on all the four sides with the same intensity, it is called a symmetrical fire in this study. These cases are used for validation of the analysis models developed in this study. The design standards include world-wide symmetric cases.

\subsection{Non-symmetric fire events concerning composite columns}

In real buildings columns may be embedded. This alters their properties in fire compared to symmetric cases. If fire does not affect all surfaces of a column in a similar way, it is called nonsymmetrical fire. Such fire is interesting because it is extremely difficult to predict how the column will behave in it. If, for instance, one side is against the fire and the other sides are insulated so that no heat transfer is possible, i.e. we refer to the so-called adiabatic conditions, then the column bows toward fire 
due to thermal expansion. Fire weakens stiffness and strength properties of the column on the side of fire compared to other parts of the cross-section. In case of a central axial load, this means that bowing due to loading is away from fire. What is the final failure mode, towards or away from fire? The initial bow imperfection and its direction may have some effect on final failure although its numerical value is small compared to deflections in fire. Is axial resistance generally higher or fire resistance time of the composite column generally longer in non-symmetrical rather than symmetrical fires? These are the key questions considered in this paper.

In [41] and related papers of the authors, composite W-shaped columns with different embedding systems are examined both experimentally and analytically. Likewise, in [42] and related papers of the authors [43, 44] concrete filled rectangular steel tubes in non-symmetrical fire are examined both experimentally and analytically. The paper excludes square columns and all columns without reinforcement. The paper [42] reports that some columns finally collapsed towards fire. Slightly nonsymmetrical temperature fields may appear in tests where the goal is symmetrical fire, as reported in [45].

In general, it can be said that very few studies on non-symmetrical fire acting on tubular composite columns have been conducted.

\subsection{Cases considered in this paper}

This paper presents results of numerical analyses for tubular composite columns in nonsymmetrical fires. Reinforced concrete-filled square steel tubes of three sizes and two buckling lengths are considered at given central axial loads. The following non-symmetrical cases are considered: ISO 834 fire acting on one side, two adjacent sides or three sides. Fire is assumed to be constant along the column. The sides which fire does not affect are assumed to be embedded. Three different embedding systems are considered: adiabatic (see above), concrete wall, and steel-mineral wool-steel sandwich panel. Reference cases are symmetrical ones. Axial loads are defined so that they represent maximum ultimate centric loads for symmetrical cases with respect to specified fire resistance times: 30 , 60, 90 and 120 minutes. Numerical results for the symmetrical cases are compared with literature data determined by analyses and tests. The idea is to define fire resistance times for non-symmetrical cases and compare them to those for symmetrical cases with the same columns. Fire resistance time was defined based on the point of time when deflections of columns have started to increase rapidly. A total of 150 cases have been analyzed.

Thermal and mechanical analyses were conducted using the finite element software ABAQUS/Standard [46]. Geometrically identical 3D finite element method (FEM) models were used both for thermal and mechanical analyses. Material models for steel tubes, reinforcement and concrete are presented in the Eurocodes [47]. The effect of initial bow imperfection is considered. The shape of the imperfection corresponded to the buckling mode of the column for the lowest buckling load in ambient conditions. All cases were analyzed using the amplitude span/666 for the imperfection towards fire to compensate the missing residual stresses in the model. Some cases were also studied with the initial imperfection away from fire. All columns were hinge supported at both ends. End nodes of the columns were forced to stay in the plane using the coupling command of ABAQUS in the mechanical analysis.

No residual stresses were assumed for the tubes. In thermal analysis full contact between the steel tube and the concrete core was assumed. In mechanical analysis the cases were analyzed supposing frictionless contact between the steel tube and the concrete core. The reinforcement was modeled with one-dimensional beam elements. 3D continuum finite elements were used both for the tube and the concrete. First thermal analysis was conducted and temperatures were stored. Then, mechanical analysis was made with a constant central axial load by increasing temperatures inside the column according to the stored temperatures. Thermal analysis was made using a 3D continuum FE model for the entire column. This was done because 1) the goal was to perform future fire tests where temperatures may change in the longitudinal direction of the column, and 2) it could give us temperatures for the mechanical model, provided that the meshes of both models were compatible, as they were in this study. To verify the numerical model, temperatures and fire resistance times in the symmetrical fire were compared to the results available in literature [26] and [48]. Temperatures were calculated using the Safir software too [49]. The results of the thermal analysis in the non-symmetrical cases were compared to the results calculated using the Safir software and the same initial data.

Preliminary results of the present study were presented in [50]. More details of the analyses and results are given in [51]. 


\section{Thermal analysis}

Cold formed steel tubes of grade S355 are considered. Sizes and lengths $L$ of the tubes are: $150 \times 150 \times 5, L=2$ and $3 \mathrm{~m} ; 250 \times 250 \times 6, L=3$ and $5 \mathrm{~m}$ and $400 \times 400 \times 10, L=3$ and $6 \mathrm{~m}$. The notation 150x150x5 means: a square tube $150 \mathrm{~mm}$ wide and high of $5 \mathrm{~mm}$ wall thickness. Roundings of the tube corners are as stated in standard [52]. Reinforcement grade is A500HW [53], carbon steel with yield strength $500 \mathrm{MPa}$ and suitable for welding. The number of bars and diameters $\mathrm{D}$ are: 150x150; $4 \mathrm{D} 12 \mathrm{~mm}, 250 \times 250 ; 4 \mathrm{D} 20 \mathrm{~mm}, 400 \times 400 ; 8 \mathrm{D} 25 \mathrm{~mm}$. The locations of the reinforcements from the concrete surface are: $150 \times 150 ; \quad 35 \mathrm{~mm}+\mathrm{D} / 2, \quad 250 \times 250 ; 45 \mathrm{~mm}+\mathrm{D} / 2, \quad 400 \times 400 ; \quad 45 \mathrm{~mm}+\mathrm{D} / 2$. The effects of different locations of reinforcement on resistance of the columns are studied in [51].

The concrete grade is $\mathrm{C} 40 / 50$ in all cases using the notations of the Eurocodes [47]. Density, conductivity and specific heat at elevated temperatures for these materials are available in the Eurocodes and are used in the analysis. Concrete moisture is $4 \%$ by weight. The upper value is used as recommended in [47] for thermal conductivity of concrete. Pressure due to vaporization of concrete is not considered in the analysis. Constant density $128 \mathrm{~kg} / \mathrm{m} 3$ and constant specific heat $840 \mathrm{~J} /(\mathrm{kgK})$ are used for mineral wool according to [54]. Bi-linear conductivity for mineral wool is used from the same reference. ISO 834 standard fire is supposed to act on the surfaces via radiation and convection. Emissivity of 0.7 is used both for steel and concrete surfaces and convection factor is $25 \mathrm{~W} / \mathrm{m} 2 \mathrm{~K}$, as stated in the Eurocodes for the ISO 834 fire.

Concrete and steel tubes were modeled with the DC3D8 brick elements of ABAQUS, while the corners of the tubes were modeled with DC3D6 elements, see [46]. Reinforcement was modeled using DC1D2 elements. Figure 1 illustrates the typical meshes both in the cross-section and along the column. All contact surfaces were modeled using the Tie option of ABAQUS to ensure heat transfer on surfaces.
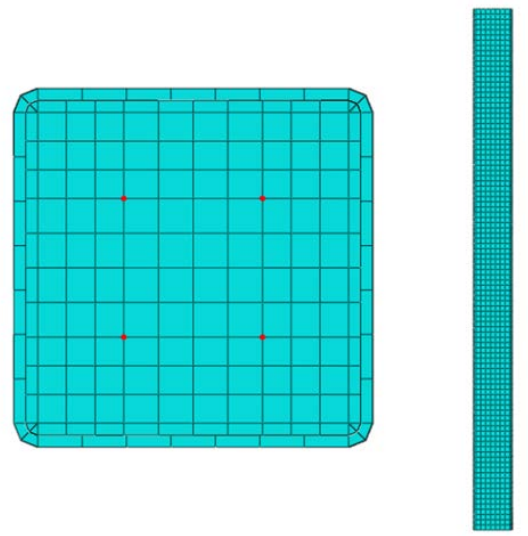

Figure 1. Typical FEM meshes used in the analysis

Three adiabatic non-symmetrical cases were considered as shown in Figure 2. Red lines show where fire acted. The other sides were adiabatic. The fourth case involved symmetrical fire.
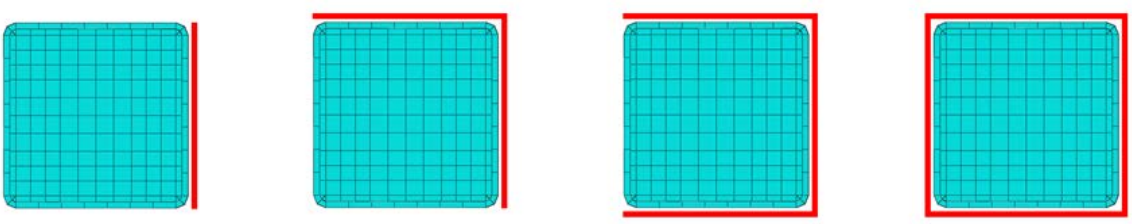

Figure 2. Adiabatic cases

Three embedding systems with concrete walls were analyzed as shown in Figure 3 . The thickness of the concrete wall was $100 \mathrm{~mm}$, but in case of fire affecting only one side the thickness is the same as the column width. In the thermal analysis, the column sides and the walls were connected with the Tie option to ensure heat transfer, meaning that no gaps were modeled between walls and columns. Three embedding systems with sandwich panels were analyzed as shown in Figure 4 for the 150x150 column. Steel faces were $0.6 \mathrm{~mm}$ thick and the mineral wool was $200 \mathrm{~mm}$ thick. Panels were modeled without connectors and corner details, as in case with concrete walls. A series of heat transfer steps lasted 240 minutes $(14,400$ seconds) with maximum increments of 60 seconds. Maximum allowable changes per increment were 25 degrees Celsius in temperature and 0.1 in emissivity. 


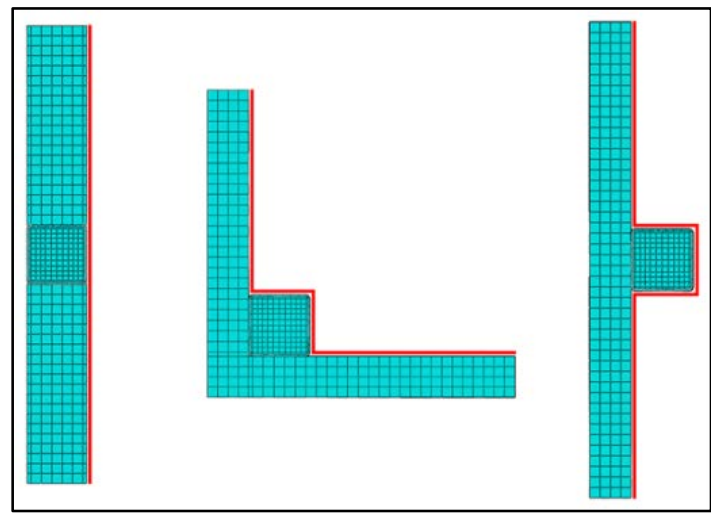

Figure 3. Embedding systems with concrete walls

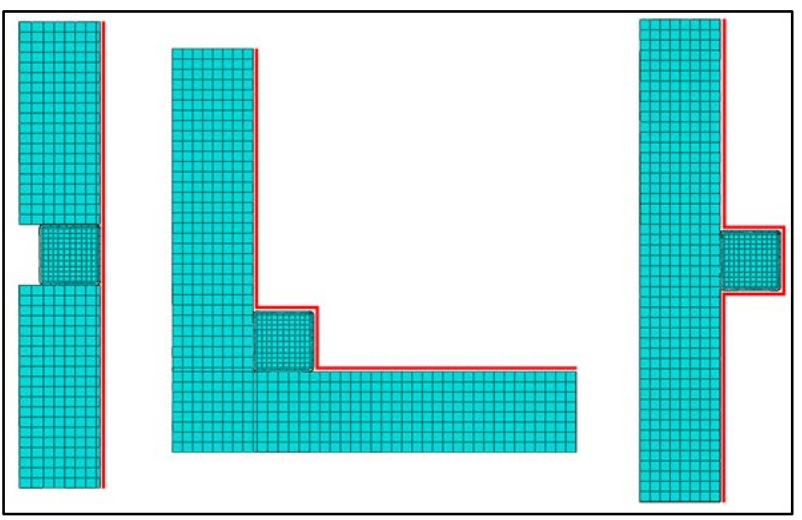

Figure 4. Embedding systems with sandwich panels

Figure 5 shows the temperatures at the cross-section from the mid-point of the column surface to the mid-point of the column in the symmetric fire cases. The temperatures were calculated using the present ABAQUS model, the Safir program [49] and taken from reference [26]. The input data in ABAQUS and the Safir models were the same.

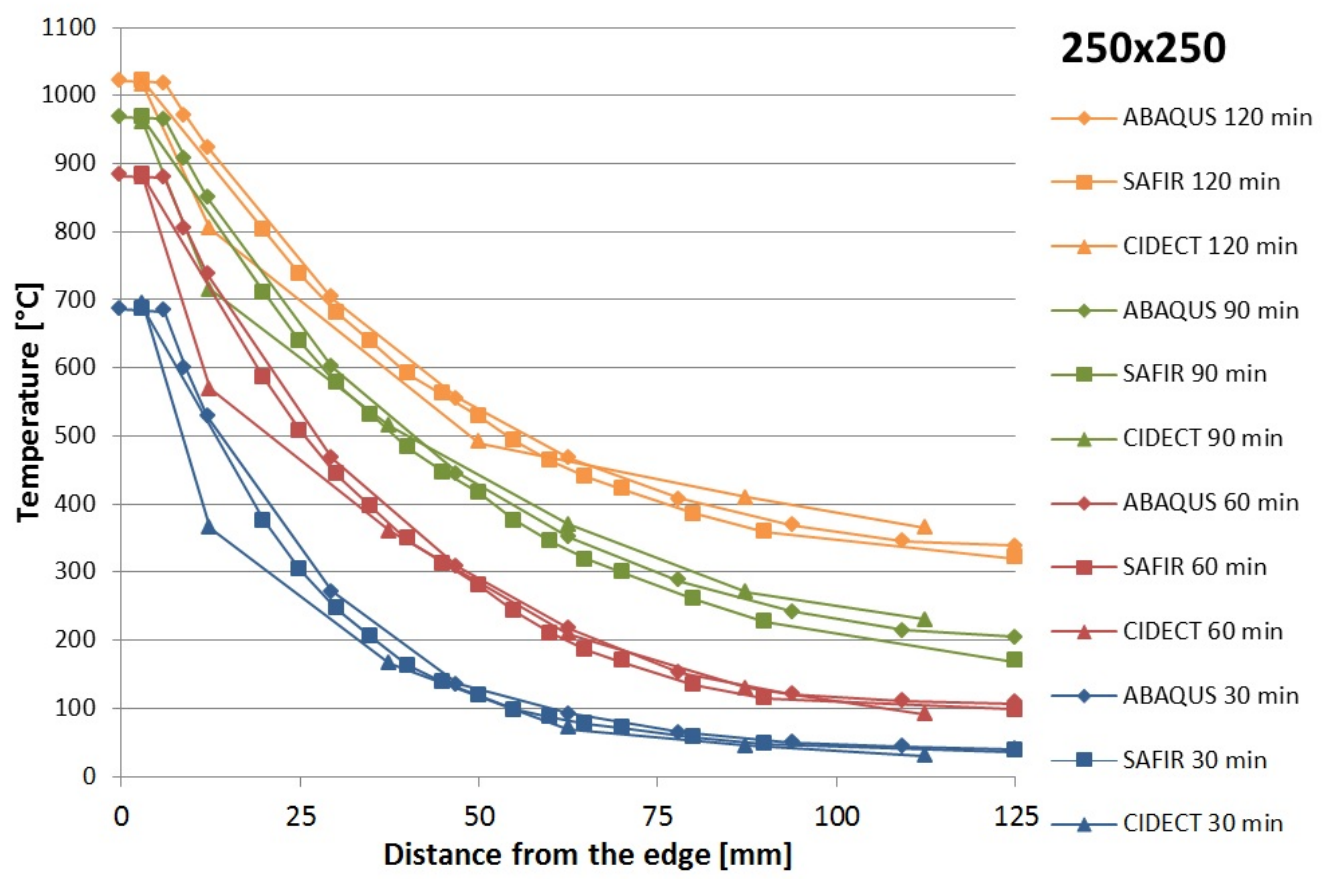

Figure 5. Temperatures in the symmetric case

The temperatures were very similar in all cases, except that the temperatures of [26] were a little lower than the other two values at the second point from the surface. Figure 6 illustrates temperature fields in a non-symmetric fire with adiabatic embedding for 250x250 columns after 60-minute ISO fire using both the Safir and the present ABAQUS model. The temperature fields are very close to each other when using both the present ABAQUS model and the Safir program. Comparisons of other cases both in symmetric and non-symmetric fires are shown in [51] and lead to the same conclusion: the developed model works reliably. Figure 7 illustrates $250 \times 250$ column temperatures after 60 -minutes ISO fire with all three embedding systems using the present ABAQUS model. 


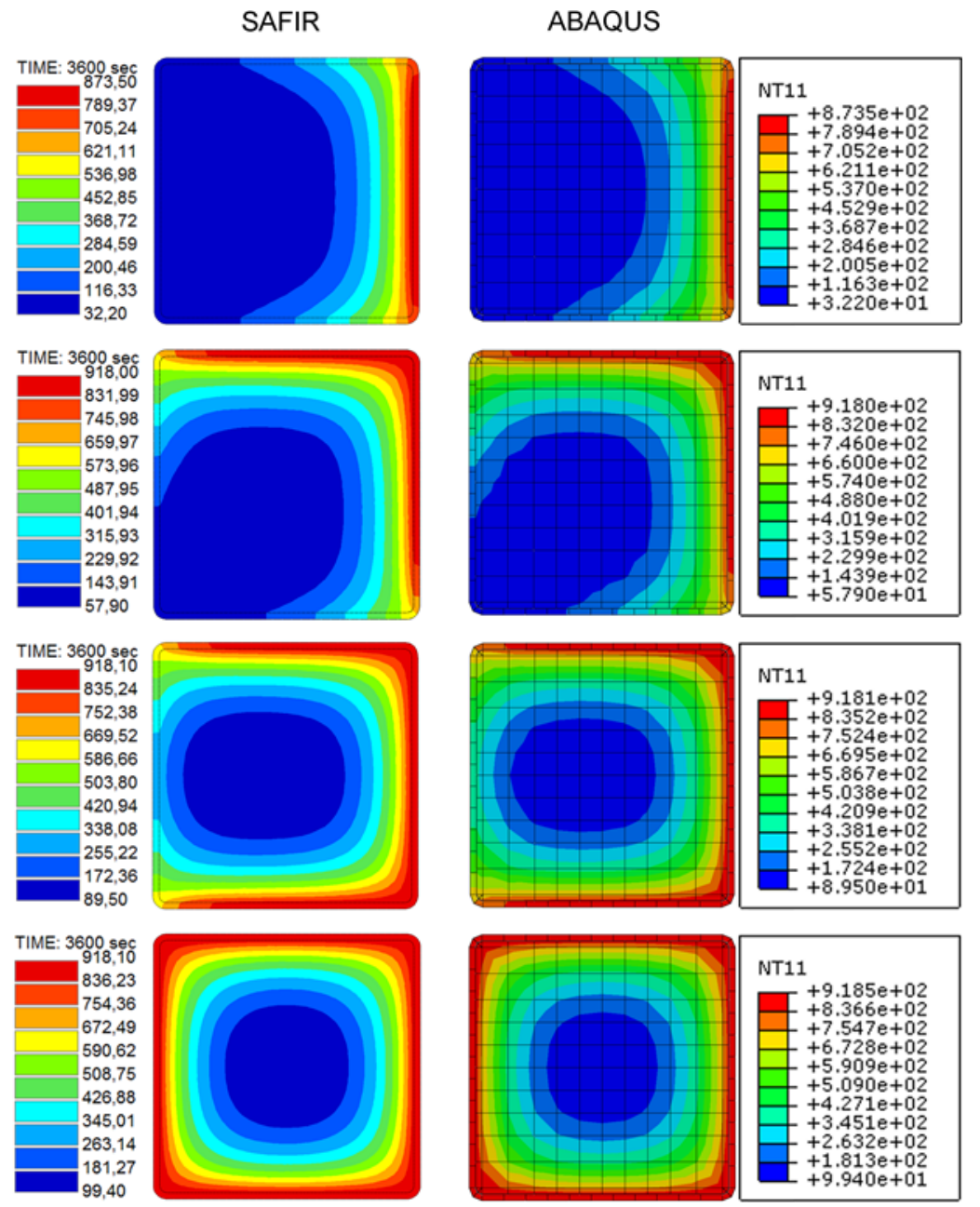

Figure 6. Temperature fields of $250 \times 250$ columns after a 60 -minute ISO fire

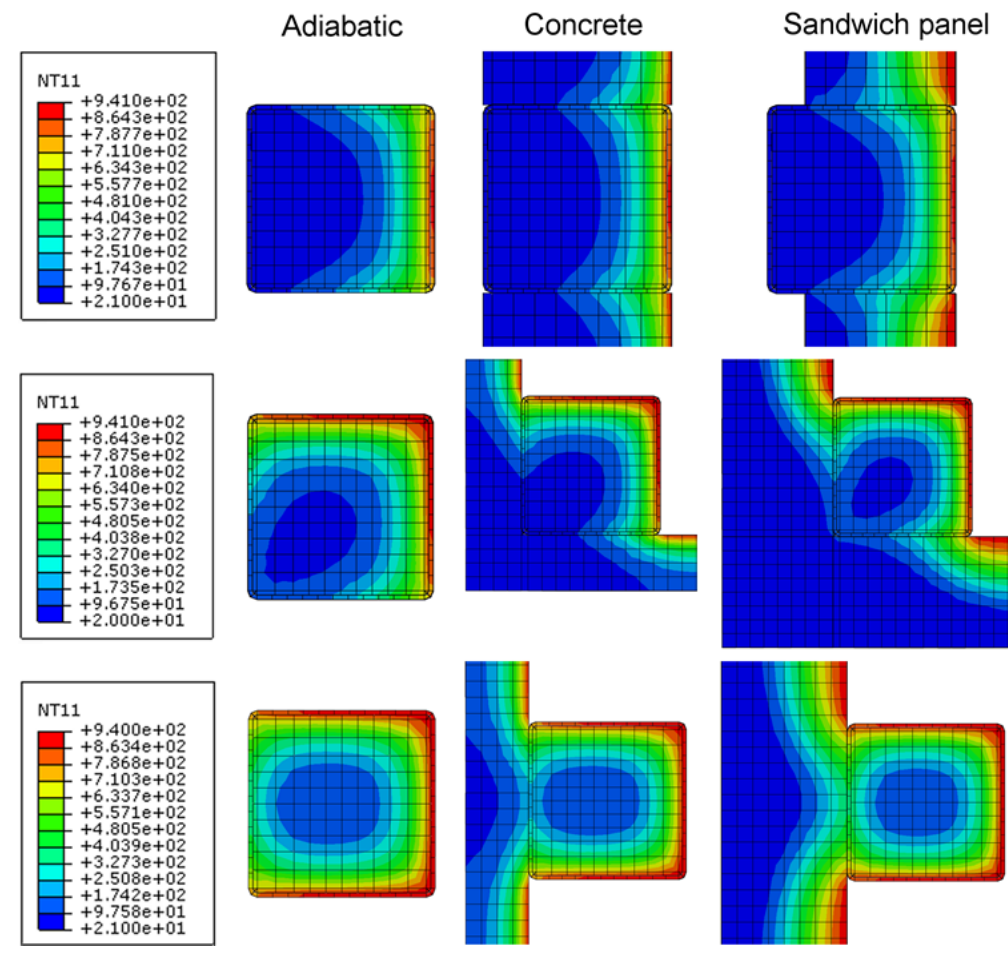

Figure 7. Temperature fields for $250 \times 250$ columns after a $60 \mathrm{~min}$ fire with different embedding systems 
The concrete wall is a good heat sink meaning that temperatures are much lower far from fire in the columns for the concrete-embedded cases than for the other two cases. It can also be seen that the temperatures for adiabatic and sandwich panel embedding are about the same. The same conclusions can be drawn for the other columns considered [51]. Figure 8 illustrates the temperatures after 240-minute ISO fire for three cases of adiabatic and one case of symmetric fire (the last one on the right) for three column sizes.

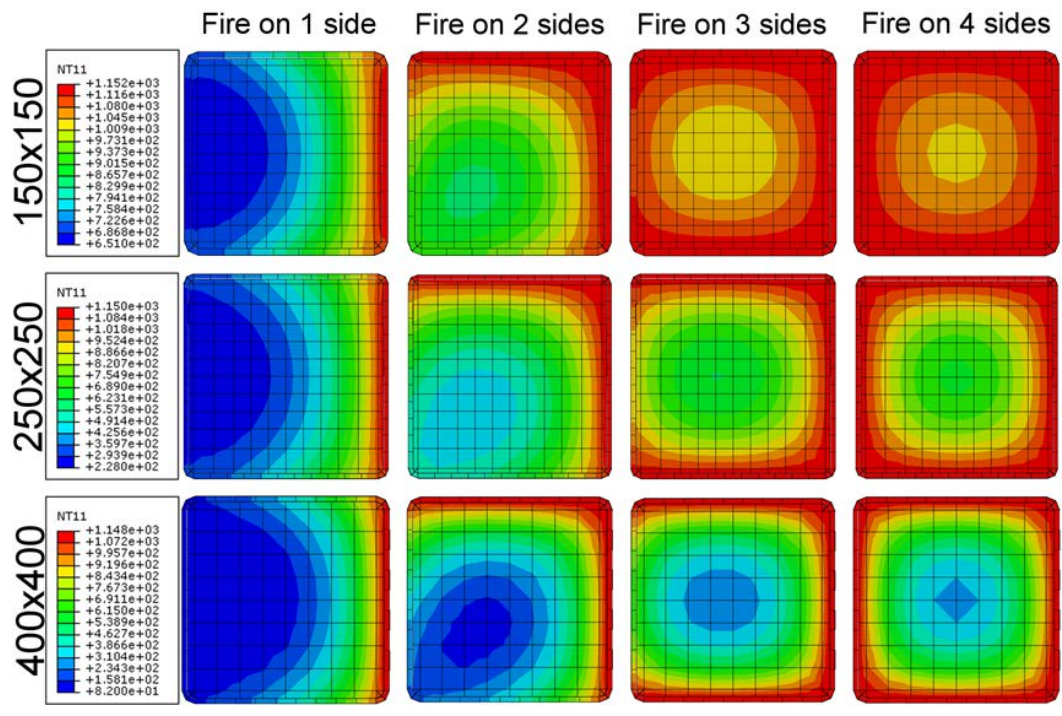

Figure 8. Temperatures for different column sizes

The temperatures are much lower in the non-symmetric cases than the symmetric ones, as expected. Non-symmetric temperatures also occur in non-symmetric fires. The differences in temperatures between symmetric fire and non-symmetric fire with fire acting on three sides are not very big, which means that the differences in fire resistance between these two cases cannot be major. In case of one $150 \times 150$ column, reinforcement was modeled with continuum elements in the thermal analysis, as well. Figure 9 illustrates the results for three adiabatic embeds and symmetric fire at about 60 minutes of ISO fire. The 3D reinforcement model causes only small differences in the temperature field near reinforcement. To summarize, the thermal analysis model seems to have worked rather well in all the cases considered.
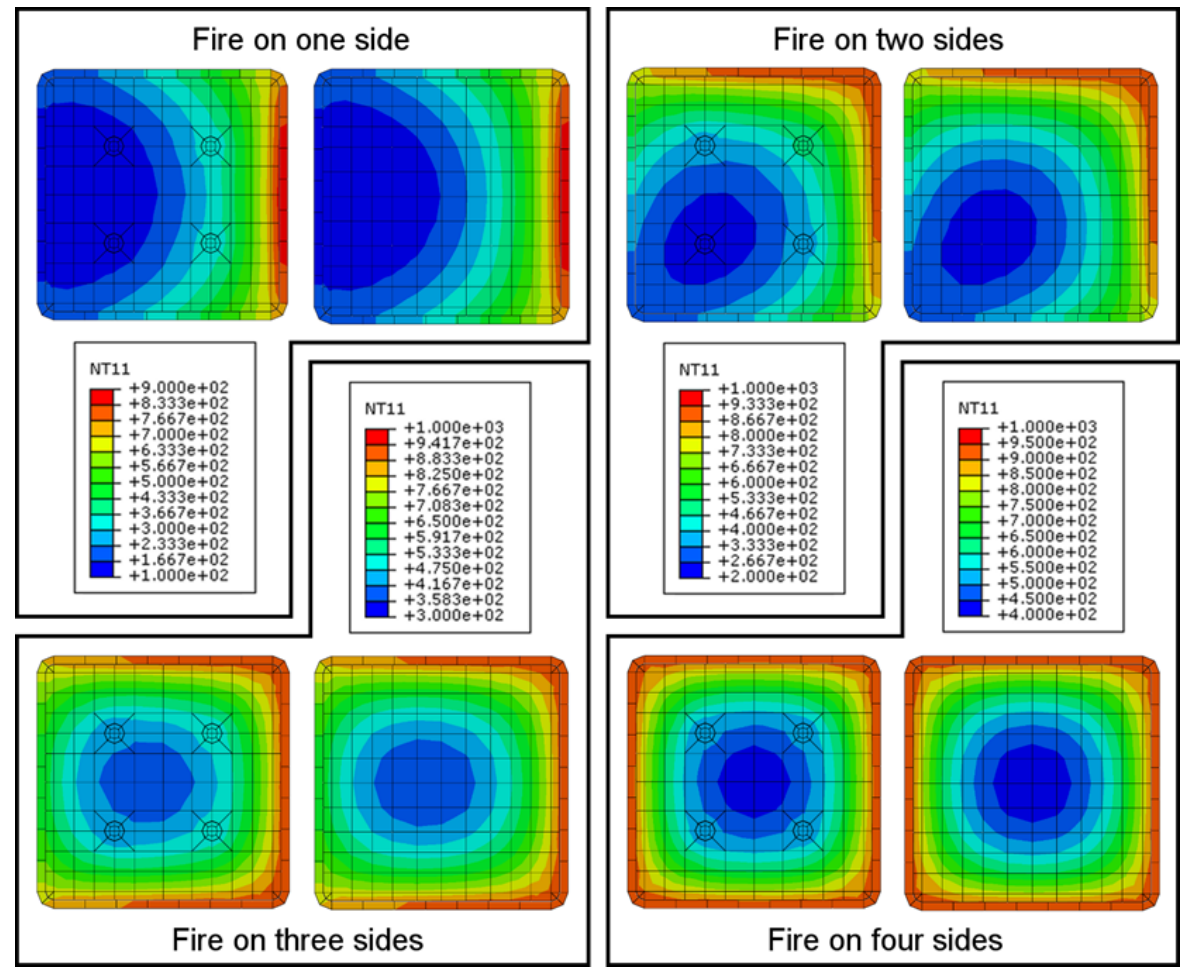

Figure 9. Temperatures using 1D and 3D finite elements as reinforcement in thermal analysis

Heinisuo M., Jokinen T. Tubular composite columns in a non-symmetrical fire 


\section{Mechanical analysis}

The concrete walls and the sandwich panels were not modeled for mechanical analysis, meaning that they did not carry any mechanical loads or support the column. Material models for tubes and reinforcement were taken from [47] Section 3.2.1 and Section 3.2.3, respectively. Elastic and plastic options of ABAQUS were used for steel with von Mises yield criteria. The stresses started to decrease linearly from 0.15 strains, reaching zero at 0.20 strains at elevated temperatures.

The material model for concrete at compression was taken from Section 3.2.2 of [47]. The elastic modulus was used as the stress/strain ratio at $40 \%$ of the maximum stress. Different stress-strain and stress-displacement relationships were tried for concrete at tension. Bi-linear and tri-linear stress-strain relationships, including those of [55], did not work properly, which led to convergence problems. Similar experiments have been reported in [55]. The same was true for the applied stress-displacement relationship similar to that reported in [56]. Finally, a simple elastic stress-strain relationship was applied to concrete on the tension side. The elastic modulus at tension was the same as in compression. Maximum tensile stresses of concrete were observed during analyses which were typically under $10 \%$ of the compressive strength of concrete.

In the mechanical analysis, the C3D8 and C3D6 brick elements of ABAQUS (see [46]) were used for the concrete and the steel tube. Reinforcement was modeled using B31 beam elements. Contact between the steel tube and the concrete was modeled using frictionless contact. Other ways to model the contact between concrete and steel tube are reported in [51]. Resistance time was based on points in time when convergence was no longer reached using ABAQUS implicit and RIKS methods.

Validation of the mechanical analysis model involves square cold-formed steel tubes $150 \times 150 \times 5$

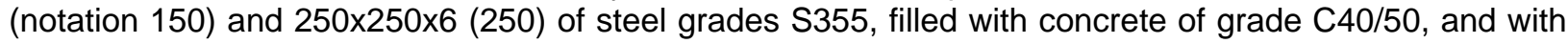
the following reinforcements: 150: 4D12, 250: 4D20 of grades A500HW. Distances between the reinforcement and steel tube are: R30: $30 \mathrm{~mm}, \mathrm{R} 60$ : $35 \mathrm{~mm}, \mathrm{R} 90: 45 \mathrm{~mm}, \mathrm{R} 120: 60 \mathrm{~mm}$, as recommended in [48]. $\mathrm{R}$ indicates the required fire resistance time for ISO fire in minutes. The buckling lengths were: 150: 2 and $3 \mathrm{~m}, 250: 3$ and $5 \mathrm{~m}$. Axial resistances for these cases are given in [48] based on analyses and experiments in symmetric fire. The non-linear fire cases were solved using the constantload analysis described below. With that technique resistance times corresponded to the points in time when convergence was no longer reached due to large displacement increments.

The fire cases were calculated with general static load (constant-load) analysis using the StaticGeneral option. Before applying heat, a step option was used to impose the axial load on the model. When the heating of the column started, the maximum time was set to 4 hours $(14,400 \mathrm{~s})$, which is the time over which the temperatures were determined. The settings for the constant-load analysis were: maximum number of increments 200, initial increment size 1, minimum 1E-005, maximum 100.

Table 1 shows the results of the validation cases. The present analysis is shown as ABAQUS in the table and TRY means the values based on [48].

Table 1. Validation cases for symmetric fire

\begin{tabular}{|c|c|c|c|c|c|c|}
\hline \multirow[t]{2}{*}{ CFT column } & $\begin{array}{l}\text { Capacity, } \\
\text { TRY [kN] }\end{array}$ & $\begin{array}{c}\text { Capacity, } \\
\text { ABAQUS [kN] }\end{array}$ & Ratio & $\begin{array}{l}\text { Capacity, } \\
\text { TRY [kN] }\end{array}$ & $\begin{array}{c}\text { Capacity, } \\
\text { ABAQUS [kN] }\end{array}$ & Ratio \\
\hline & \multicolumn{3}{|c|}{ R30 } & \multicolumn{3}{|c|}{ R60 } \\
\hline $150 \times 150 \times 5,4 \mathrm{~T} 12,2 \mathrm{~m}$ & 565 & 476 & $84 \%$ & 260 & 174 & $67 \%$ \\
\hline $150 \times 150 \times 5,4 \mathrm{~T} 12,3 \mathrm{~m}$ & 330 & 303 & $92 \%$ & 140 & 110 & $79 \%$ \\
\hline $250 \times 250 \times 5,4 \mathrm{~T} 20,3 \mathrm{~m}$ & 2090 & 1975 & $94 \%$ & 1180 & 1094 & $93 \%$ \\
\hline $250 \times 250 \times 5,4 \mathrm{~T} 20,5 \mathrm{~m}$ & 1190 & 1171 & $98 \%$ & 595 & 634 & $107 \%$ \\
\hline $400 \times 400 \times 10,8 \mathrm{~T} 25,3 \mathrm{~m}$ & 8380 & 8031 & $96 \%$ & 5810 & 5942 & $102 \%$ \\
\hline $400 \times 400 \times 10,8 \mathrm{~T} 25,6 \mathrm{~m}$ & 5890 & 5624 & $95 \%$ & 3460 & 3564 & $103 \%$ \\
\hline CFT column & \multicolumn{3}{|c|}{ R90 } & \multicolumn{3}{|c|}{ R120 } \\
\hline $150 \times 150 \times 5,4 \mathrm{~T} 12,2 \mathrm{~m}$ & - & - & - & - & - & - \\
\hline $150 \times 150 \times 5,4 \mathrm{~T} 12,3 \mathrm{~m}$ & - & - & - & - & - & - \\
\hline $250 \times 250 \times 5,4 \mathrm{~T} 20,3 \mathrm{~m}$ & 780 & 728 & $93 \%$ & 620 & 443 & $71 \%$ \\
\hline $250 \times 250 \times 5,4 \mathrm{~T} 20,5 \mathrm{~m}$ & 365 & 406 & $111 \%$ & 280 & 233 & $83 \%$ \\
\hline $400 \times 400 \times 10,8 \mathrm{~T} 25,3 \mathrm{~m}$ & 4580 & 4868 & $106 \%$ & 4200 & 4053 & $97 \%$ \\
\hline $400 \times 400 \times 10,8 \mathrm{~T} 25,6 \mathrm{~m}$ & 2430 & 2625 & $108 \%$ & 2210 & 2045 & $93 \%$ \\
\hline
\end{tabular}


The used model gives results which are close to [48] but for the smallest columns 150x150x5 and $250 \times 250 \times 5$ (R120). In these cases the used model is conservative. Other validation cases of the used model are given in [48]. Although the FEM model is very coarse with respect to the thickness of the steel tube (only one element), the results are good in the validation cases and can be used to represent the failure modes of the columns in the symmetric fire cases. The failure modes are expected to be similar in the non-symmetric fire cases. The bold values in Figure 10 were used as axial loads for the nonsymmetric fires.

\section{Non-symmetric cases}

In some non-symmetric cases interpretation of the results was straightforward. Figure 10 presents horizontal displacements versus time for two 250×250 columns when fire acted on two adjacent sides (code 2S) and the two other sides were adiabatic.

Fire resistance time in these cases was about 59 minutes $(5 \mathrm{~m}$ column) and 143 minutes ( $3 \mathrm{~m}$ column) after which diagonal displacements started to grow rapidly. In the symmetric fire resistance times with these loads were 30 and 57 minutes, respectively. It can also be seen that the column with $\mathrm{L}=3 \mathrm{~m}$ finally buckled towards fire and the column with $L=5 \mathrm{~m}$ finally buckled away from fire.

In some cases final fire resistance time could not be established as clearly. In the case described in Figure 11 on the left, the analysis stopped for an undetermined reason, while in the case on the right, the analysis stopped as the time limit of 4 hours was reached. Code C2S means concrete embedding (C) and fire on two adjacent sides (2S). Code C1S means concrete embedding (C) and fire on one side (1S).Codes that do not begin with a letter refer to adiabatic embedding, and those that begin with the letter "S" refer to sandwich embedding. In the cases shown in Figure 11 no reliable fire resistance time was found, but the main finding is that the target resistance time (30 and 60 minutes) was greatly exceeded.
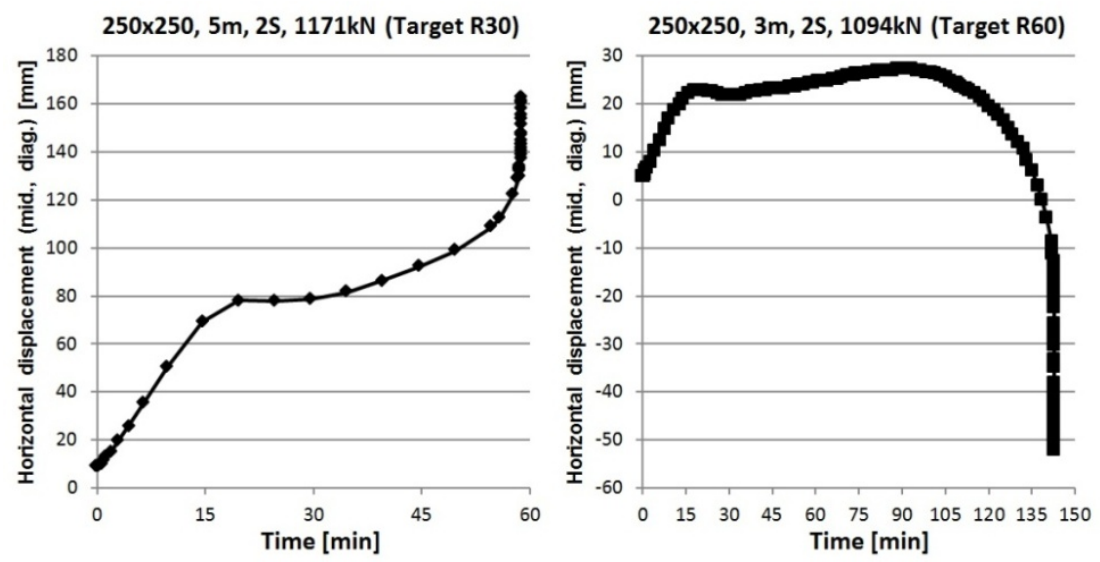

Figure 10. Column $250 \times 250$ in a non-symmetric fire

Table 2 includes the results for the non-symmetric cases considered. Unclear cases similar to those of Figure 11 are shown in red. Table 2 also includes fire resistance time for the symmetric cases (4S) which were calculated using constant-load analysis. They are close to the target values but in the case of $400 \times 400$ columns target time is 90 and 120 minutes.
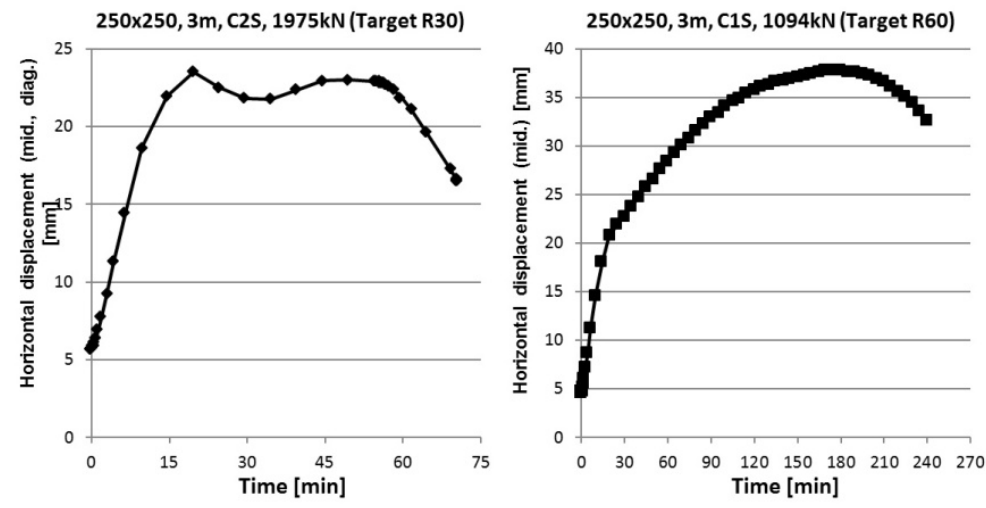

Figure 11. 250x250 column with concrete embeds in non-symmetric fires

Heinisuo M., Jokinen T. Tubular composite columns in a non-symmetrical fire 
Table 2. Fire resistance time of non-symmetric cases

\begin{tabular}{|c|c|c|c|c|c|c|c|c|c|c|c|c|c|}
\hline \multirow{2}{*}{ \# } & \multirow{2}{*}{ CFT column } & \multirow{2}{*}{ Target } & \multirow{2}{*}{ Load $[\mathrm{kN}]$} & \multicolumn{10}{|c|}{ Fire resistance time [min] } \\
\hline & & & & $4 S$ & $3 S$ & $2 S$ & 15 & C3S & C2S & C1S & S3S & S2S & S1S \\
\hline 1 & & & & 32.2 & 46.2 & 59.7 & 114.6 & & 76.5 & 132.7 & 43.5 & 55.8 & 111.1 \\
\hline 2 & & & & 65.4 & 89.3 & 113.2 & 75.4 & 98.3 & 154.2 & 212.1 & 84.9 & 110.1 & 170.0 \\
\hline 3 & & & & 29.8 & 36.5 & 42.6 & 111.0 & 35.7 & 42.2 & 105.9 & 36.4 & 41.3 & 86.1 \\
\hline 4 & $150 x$ & & & 72.6 & 72.4 & 108.1 & 212.0 & 78.0 & 139.0 & 240.0 & 71.8 & 103.9 & 183.5 \\
\hline 5 & $250>$ & R3 & 1975 & 31.2 & 47.7 & 77.7 & 144.2 & 47.2 & 70.5 & 186.2 & 47.1 & 73.3 & 160.2 \\
\hline 6 & & & & 56.9 & 82.2 & 142.7 & 240.0 & 87.9 & 179.0 & 240.0 & 80.1 & 137.5 & 237.6 \\
\hline 7 & & & & 85.4 & 110.6 & 177.9 & 240.0 & 114.0 & 230.2 & 240.0 & 109.6 & 176.5 & 240.0 \\
\hline 8 & $250 x$ & R12 & & 119.3 & 141.6 & 232.4 & 240.0 & 147.1 & 240.0 & 240.0 & 140.1 & 226.3 & 240.0 \\
\hline 9 & & & 171 & 30.3 & 45.6 & 58.8 & 87.6 & 44.7 & 52.3 & 94.8 & 44.6 & 64.7 & 87.6 \\
\hline 10 & & & & 56.3 & 65.7 & 143.1 & 205.5 & 65.0 & 128.8 & 240.0 & 65.7 & 127.7 & 205.5 \\
\hline 11 & $250 \times 250,5$ & & & 89.7 & 119.2 & 224.8 & 240.0 & 106.4 & 169.9 & 240.0 & 103.5 & 215.6 & 240.0 \\
\hline 12 & $250 \times 25$ & & & 127.1 & 146.1 & 240.0 & 240.0 & 193.9 & 240.0 & 240.0 & 144.4 & 38.2 & 240.0 \\
\hline 13 & $400 x$ & & 31 & 27.4 & 34.8 & 56.1 & 125.8 & 35.4 & \begin{tabular}{|l|}
57.7 \\
\end{tabular} & 136.6 & 34.4 & 55.0 & - \\
\hline 14 & $400 \times 400,3 \mathrm{~m}$ & & & 55.7 & 65.7 & 124.3 & 240.0 & 68.8 & 130.4 & 240.0 & \begin{tabular}{|l|}
63.8 \\
\end{tabular} & 116.2 & - \\
\hline 15 & $400 \times 400,3 \mathrm{~m}$ & & & 77.3 & 81.5 & 173.4 & 240.0 & 79.6 & 185.7 & 240.0 & 91.5 & 165.4 & - \\
\hline 16 & $400 \times 400,3 \mathrm{~m}$ & $\mathrm{R} 120$ & & 91.8 & 85.5 & 217.3 & 240.0 & 85.8 & 235.6 & 240.0 & 98.8 & 205.2 & - \\
\hline 17 & $400 \times 400,6 \mathrm{~m}$ & & 5624 & 29.1 & 42.6 & 79.2 & 107.3 & 39.8 & 94.8 & 128.5 & 42.0 & 75.4 & \\
\hline 18 & $400 \times 400,6 \mathrm{~m}$ & $\mathrm{R} 60$ & 3564 & 55.1 & 82.7 & 174.3 & 240.0 & 97.1 & 219.5 & 240.0 & 80.2 & 168.7 & - \\
\hline 19 & & & & 75.4 & 121.0 & 239.6 & 240.0 & 131.6 & 240.0 & 240.0 & 118.4 & 39.3 & - \\
\hline 20 & $400 \times 400,6 \mathrm{~m}$ & R120 & 2045 & 102.1 & 155.7 & 240.0 & 240.0 & 158.1 & 240.0 & 240.0 & 153.4 & 240.0 & \\
\hline
\end{tabular}
Table 3 .

All fire resistance time was divided by that of case $4 \mathrm{~S}$ (symmetric fire). The ratios are presented in

Table 3. Ratios of fire resistance time: non-symmetric versus symmetric fire

\begin{tabular}{|c|c|c|c|c|c|c|c|c|c|c|c|c|c|}
\hline \multirow{2}{*}{$\#$} & \multirow{2}{*}{ CFT column } & & & \multicolumn{10}{|c|}{ Ratio to 4S case } \\
\cline { 6 - 14 } & & Target & Load [kN] & 4S & 3S & 2S & 1S & C3S & C2S & C1S & S3S & S2S & S1S \\
\hline 1 & $150 \times 150,2 \mathrm{~m}$ & R30 & 476 & 1.00 & 1.43 & 1.85 & 3.56 & 1.52 & 2.37 & 4.12 & 1.35 & 1.73 & 3.45 \\
\hline 2 & $150 \times 150,2 \mathrm{~m}$ & $\mathrm{R} 60$ & 174 & 1.00 & 1.37 & 1.73 & 2.68 & 1.50 & 2.36 & 3.24 & 1.30 & 1.68 & 2.60 \\
\hline 3 & $150 \times 150,3 \mathrm{~m}$ & $\mathrm{R} 30$ & 303 & 1.00 & 1.23 & 1.43 & 3.73 & 1.20 & 1.42 & 3.56 & 1.22 & 1.39 & 2.89 \\
\hline 4 & $150 \times 150,3 \mathrm{~m}$ & $\mathrm{R} 60$ & 110 & 1.00 & 1.00 & 1.49 & 2.92 & 1.07 & 1.91 & 3.30 & 0.99 & 1.43 & 2.53 \\
\hline 5 & $250 \times 250,3 \mathrm{~m}$ & $\mathrm{R} 30$ & 1975 & 1.00 & 1.53 & 2.49 & 4.63 & 1.51 & 2.26 & 5.97 & 1.51 & 2.35 & 5.14 \\
\hline 6 & $250 \times 250,3 \mathrm{~m}$ & $\mathrm{R} 60$ & 1094 & 1.00 & 1.44 & 2.51 & 4.22 & 1.54 & 3.15 & 4.22 & 1.41 & 2.42 & 4.18 \\
\hline 7 & $250 \times 250,3 \mathrm{~m}$ & $\mathrm{R} 90$ & 728 & 1.00 & 1.29 & 2.08 & 2.81 & 1.33 & 2.70 & 2.81 & 1.28 & 2.07 & 2.81 \\
\hline 8 & $250 \times 250,3 \mathrm{~m}$ & $\mathrm{R} 120$ & 443 & 1.00 & 1.19 & 1.95 & 2.01 & 1.23 & 2.01 & 2.01 & 1.17 & 1.90 & 2.01 \\
\hline 9 & $250 \times 250,5 \mathrm{~m}$ & $\mathrm{R} 30$ & 1171 & 1.00 & 1.50 & 1.94 & 2.89 & 1.47 & 1.72 & 3.13 & 1.47 & 2.14 & 2.89 \\
\hline 10 & $250 \times 250,5 \mathrm{~m}$ & $\mathrm{R} 60$ & 634 & 1.00 & 1.17 & 2.54 & 3.65 & 1.15 & 2.29 & 4.26 & 1.17 & 2.27 & 3.65 \\
\hline 11 & $250 \times 250,5 \mathrm{~m}$ & $\mathrm{R} 90$ & 406 & 1.00 & 1.33 & 2.51 & 2.68 & 1.19 & 1.89 & 2.68 & 1.15 & 2.40 & 2.68 \\
\hline 12 & $250 \times 250,5 \mathrm{~m}$ & $\mathrm{R} 120$ & 233 & 1.00 & 1.15 & 1.89 & 1.89 & 1.53 & 1.89 & 1.89 & 1.14 & 1.87 & 1.89 \\
\hline 13 & $400 \times 400,3 \mathrm{~m}$ & $\mathrm{R} 30$ & 8031 & 1.00 & 1.27 & 2.05 & 4.60 & 1.30 & 2.11 & 4.99 & 1.26 & 2.01 & - \\
\hline 14 & $400 \times 400,3 \mathrm{~m}$ & $\mathrm{R} 60$ & 5942 & 1.00 & 1.18 & 2.23 & 4.31 & 1.23 & 2.34 & 4.31 & 1.15 & 2.09 & - \\
\hline 15 & $400 \times 400,3 \mathrm{~m}$ & $\mathrm{R} 90$ & 4868 & 1.00 & 1.05 & 2.24 & 3.11 & 1.03 & 2.40 & 3.11 & 1.18 & 2.14 & - \\
\hline 16 & $400 \times 400,3 \mathrm{~m}$ & $\mathrm{R} 120$ & 4053 & 1.00 & 0.93 & 2.37 & 2.62 & 0.93 & 2.57 & 2.62 & 1.08 & 2.24 & - \\
\hline 17 & $400 \times 400,6 \mathrm{~m}$ & $\mathrm{R} 30$ & 5624 & 1.00 & 1.46 & 2.72 & 3.69 & 1.37 & 3.26 & 4.41 & 1.44 & 2.59 & - \\
\hline 18 & $400 \times 400,6 \mathrm{~m}$ & $\mathrm{R} 60$ & 3564 & 1.00 & 1.50 & 3.17 & 4.36 & 1.76 & 3.99 & 4.36 & 1.46 & 3.06 & - \\
\hline 19 & $400 \times 400,6 \mathrm{~m}$ & $\mathrm{R} 90$ & 2625 & 1.00 & 1.60 & 3.18 & 3.18 & 1.74 & 3.18 & 3.18 & 1.57 & 3.17 & - \\
\hline 20 & $400 \times 400,6 \mathrm{~m}$ & $\mathrm{R} 120$ & 2045 & 1.00 & 1.53 & 2.35 & 2.35 & 1.55 & 2.35 & 2.35 & 1.50 & 2.35 & - \\
\hline
\end{tabular}


Almost all ratios are over 1.0 which means that in the non-symmetric cases fire resistance was at least as good as in the symmetric cases and generally much better. The means of fire resistance time in the non-symmetric fire versus symmetric fire are presented in Figure 12 with different embedding systems.

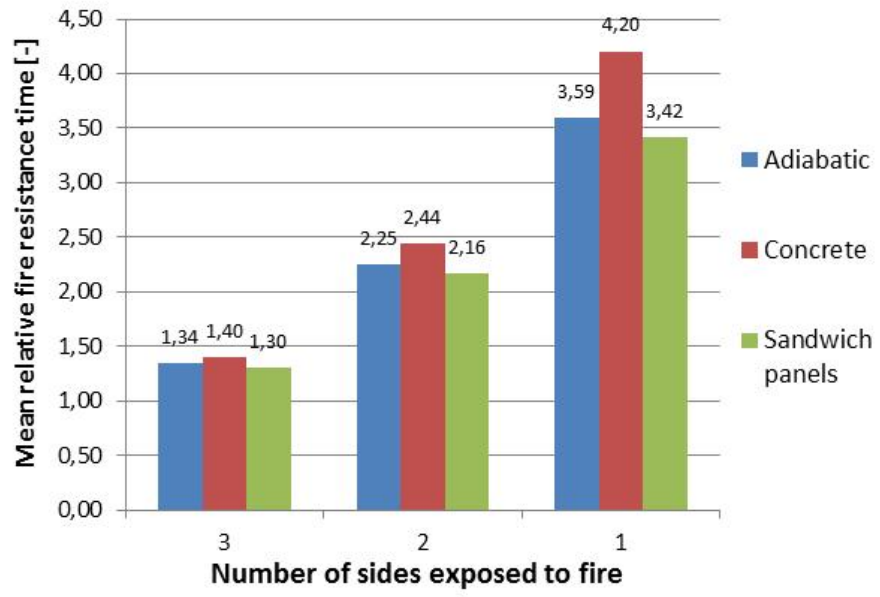

Figure 12. Mean relative fire resistance times in non-symmetric fires

Concrete embedding seems to be most efficient in increasing fire resistance time while adiabatic and sandwich panels are less effective but nearly equal to each other in this respect. In [42] the ratio of increase in fire resistance time compared to the symmetric fire for 3-side non-symmetric fire was 1.1, for 2-side fire 2.6 and for 1-side fire 4.8. The means in Figure 12 are 1.34, 2.25 and 3.59, respectively. In [42] fire on two sides was at opposite sides of the column, not on adjacent sides as in this study. Moreover, [42] used unreinforced square columns while in case 15 the narrow side of the column was in fire and in case $3 S$ two wide sides and one narrow side, which explains the differences between these cases.

All these cases were calculated assuming initial bowing L/666 towards fire. In case $2 S$ the initial bowing was in the diagonal direction. Table 4 shows the directions to which the columns finally buckled, $A=$ away from fire, $T=$ towards fire.

Table 4. Buckling directions of the columns in non-symmetric fire

\begin{tabular}{|c|c|c|c|c|c|c|c|c|c|c|c|c|c|c|c|}
\hline \multirow{2}{*}{ \# } & \multirow{2}{*}{ CFT column } & \multirow{2}{*}{ Target } & \multirow{2}{*}{$\begin{array}{c}\text { Load } \\
{[\mathrm{kN}]}\end{array}$} & \multicolumn{9}{|c|}{ Buckling direction } & \multirow{2}{*}{$\begin{array}{c}\mathbf{n}_{\text {towards }} \\
{[-]}\end{array}$} & \multirow{2}{*}{$\begin{array}{c}\mathbf{n}_{\text {away }} \\
{[-]}\end{array}$} & \multirow{2}{*}{$\begin{array}{c}\mathbf{n}_{\text {unknowr }} \\
{[-]}\end{array}$} \\
\hline & & & & $3 S$ & $2 S$ & 15 & C3S & C2S & C1S & S3S & S2S & S1S & & & \\
\hline 1 & $150 \times 150,2 \mathrm{~m}$ & R30 & 476 & $\mathrm{~T}$ & A & A & $\mathrm{T}$ & A & A & $\mathrm{T}$ & A & A & 3 & 6 & 0 \\
\hline 2 & $150 \times 150,2 \mathrm{~m}$ & R60 & 174 & $\mathrm{~T}$ & A & A & A & A & A & $\mathrm{T}$ & A & A & 2 & 7 & 0 \\
\hline 3 & $150 \times 150,3 \mathrm{~m}$ & R30 & 303 & $\mathrm{~T}$ & $\mathrm{~T}$ & $\mathrm{~T}$ & $\mathrm{~T}$ & $\mathrm{~T}$ & $\mathrm{~T}$ & $\mathrm{~T}$ & $\mathrm{~T}$ & $\mathrm{~T}$ & 9 & 0 & 0 \\
\hline 4 & $150 \times 150,3 \mathrm{~m}$ & $\mathrm{R} 60$ & 110 & $\mathrm{~T}$ & $\mathrm{~T}$ & A & $\mathrm{T}$ & $\mathrm{T}$ & - & $\mathrm{T}$ & $\mathrm{T}$ & $\mathrm{T}$ & 7 & 1 & 1 \\
\hline 5 & $250 \times 250,3 \mathrm{~m}$ & R30 & 1975 & $\mathrm{~T}$ & $\mathrm{~A}$ & $\mathrm{~A}$ & $\mathrm{~T}$ & $\mathrm{~A}$ & A & $\mathrm{T}$ & $\mathrm{A}$ & $\mathrm{A}$ & 3 & 6 & 0 \\
\hline 6 & $250 \times 250,3 \mathrm{~m}$ & $\mathrm{R} 60$ & 1094 & $\mathrm{~A}$ & $\mathrm{~A}$ & $\mathrm{~A}$ & $\mathrm{~A}$ & $\mathrm{~A}$ & $\mathrm{~A}$ & $\mathrm{~A}$ & $\mathrm{~A}$ & $\mathrm{~A}$ & 0 & 9 & 0 \\
\hline 7 & $250 \times 250,3 \mathrm{~m}$ & $\mathrm{R} 90$ & 728 & A & A & - & A & A & - & A & A & $\mathrm{A}$ & 0 & 7 & 2 \\
\hline 8 & $250 \times 250,3 \mathrm{~m}$ & R120 & 443 & $\mathrm{~A}$ & $\mathrm{~A}$ & - & $\mathrm{A}$ & - & - & $\mathrm{A}$ & $\mathrm{A}$ & - & 0 & 5 & 4 \\
\hline 9 & $250 \times 250,5 \mathrm{~m}$ & R30 & 1171 & $\mathrm{~T}$ & $\mathrm{~T}$ & $\mathrm{~T}$ & $\mathrm{~T}$ & $\mathrm{~T}$ & $\mathrm{~T}$ & $\mathrm{~T}$ & $\mathrm{~T}$ & $\mathrm{~T}$ & 9 & 0 & 0 \\
\hline 10 & $250 \times 250,5 \mathrm{~m}$ & $\mathrm{R} 60$ & 634 & $\mathrm{~T}$ & $\mathrm{~T}$ & $\mathrm{~T}$ & $\mathrm{~T}$ & $\mathrm{~T}$ & $\mathrm{~T}$ & $\mathrm{~T}$ & $\mathrm{~T}$ & $\mathrm{~T}$ & 9 & 0 & 0 \\
\hline 11 & $250 \times 250,5 \mathrm{~m}$ & R90 & 406 & $\mathrm{~T}$ & $\mathrm{~T}$ & - & $\mathrm{T}$ & $\mathrm{T}$ & - & $\mathrm{T}$ & $T$ & - & 6 & 0 & 3 \\
\hline 12 & $250 \times 250,5 \mathrm{~m}$ & R120 & 233 & $\mathrm{~T}$ & - & - & A & $\mathrm{T}$ & - & $\mathrm{T}$ & $\mathrm{T}$ & - & 4 & 1 & 4 \\
\hline 13 & $400 \times 400,3 \mathrm{~m}$ & R30 & 8031 & A & A & A & A & A & A & A & A & - & 0 & 8 & 1 \\
\hline 14 & $400 \times 400,3 \mathrm{~m}$ & $\mathrm{R} 60$ & 5942 & $\mathrm{~A}$ & $\mathrm{~A}$ & A & $\mathrm{A}$ & $\mathrm{A}$ & $\mathrm{A}$ & $\mathrm{A}$ & $\mathrm{A}$ & - & 0 & 8 & 1 \\
\hline 15 & $400 \times 400,3 \mathrm{~m}$ & $\mathrm{R} 90$ & 4868 & $\mathrm{~A}$ & A & A & A & A & A & A & A & - & 0 & 8 & 1 \\
\hline 16 & $400 \times 400,3 \mathrm{~m}$ & $\mathrm{R} 120$ & 4053 & $\mathrm{~A}$ & $\mathrm{~A}$ & - & $\mathrm{A}$ & $\mathrm{A}$ & - & $\mathrm{A}$ & $\mathrm{A}$ & - & 0 & 6 & 3 \\
\hline 17 & $400 \times 400,6 \mathrm{~m}$ & R30 & 5624 & $\mathrm{~T}$ & A & $\mathrm{T}$ & $\mathrm{T}$ & $\mathrm{A}$ & $\mathrm{T}$ & $\mathrm{T}$ & A & - & 5 & 3 & 1 \\
\hline 18 & $400 \times 400,6 \mathrm{~m}$ & $\mathrm{R} 60$ & 3564 & A & $\mathrm{A}$ & - & $\mathrm{A}$ & $\mathrm{A}$ & - & $\mathrm{T}$ & $\mathrm{A}$ & - & 1 & 5 & 3 \\
\hline 19 & $400 \times 400,6 \mathrm{~m}$ & $\mathrm{R} 90$ & 2625 & $\mathrm{~A}$ & $\mathrm{~A}$ & - & $\mathrm{A}$ & $\mathrm{T}$ & - & $\mathrm{A}$ & $\mathrm{A}$ & - & 1 & 5 & 3 \\
\hline 20 & $400 \times 400,6 \mathrm{~m}$ & $\mathrm{R} 120$ & 2045 & $\mathrm{~A}$ & $\mathrm{~T}$ & - & $\mathrm{A}$ & $\mathrm{T}$ & - & $\mathrm{A}$ & $\mathrm{T}$ & - & 3 & 3 & 3 \\
\hline
\end{tabular}

Heinisuo M., Jokinen T. Tubular composite columns in a non-symmetrical fire 
Slender columns have a tendency to buckle toward fire and stocky columns away from fire.

All columns that buckled away from fire had a slightly longer relative fire resistance time comparing to those that buckled towards fire. One reason for this may be the direction of the initial bow imperfection which was towards fire. Some cases were analyzed again by setting imperfection away from fire. The results are shown in Figure 13.
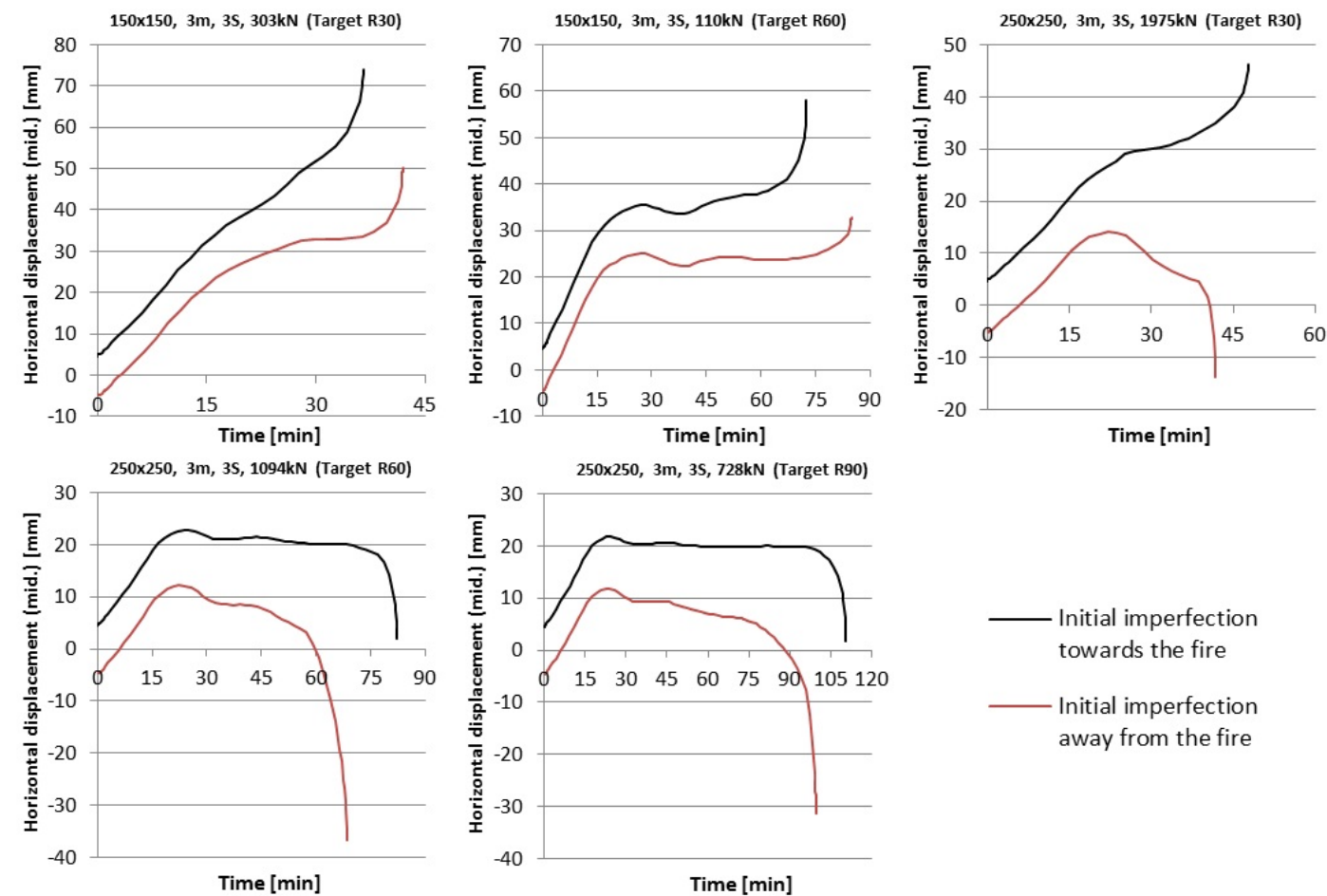

Figure 13. Effect of the direction of initial bow imperfection

Approximate reduction factors based on this effect are given in [51]. The general rule is that initial bow imperfections in both directions should be studied when determining fire resistance of columns in non-symmetric fire.

The effect of the amplitude of the initial bow imperfection was studied using constant-temperature analysis. Figure 14 illustrates the results for a 250x250, L = 5 m column in 30-minute symmetric fire.

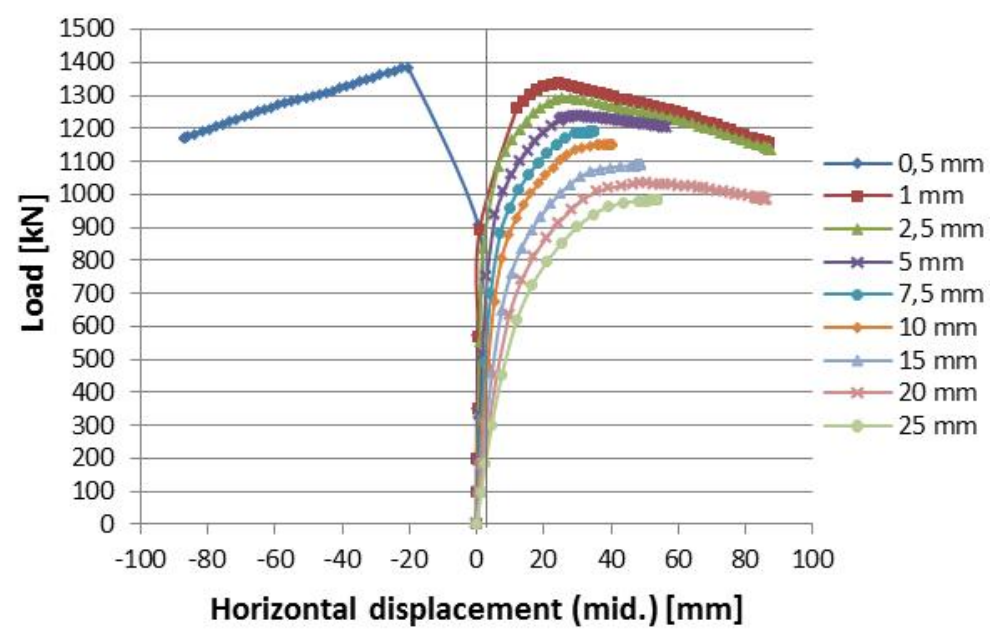

Figure 14. Effect of the amplitude of initial bow imperfection

When the amplitude is larger than, let us say L/2000 (2.5 mm), the maximum load decreases almost linearly. Amplitude L/666 $(7.5 \mathrm{~mm})$ was used in this study. This amplitude was used instead of normal L/1000 or L/750 to compensate the missing residual stresses in the model. If the amplitude is very small ( 0.5 or $1 \mathrm{~mm}$ in Figure 14$)$, the results may be unreliable.

Heinisuo M., Jokinen T. Tubular composite columns in a non-symmetrical fire 


\section{Conclusions}

The main conclusions are following.

1. Composite tubular columns resisted the same axial load longer in non-symmetric fire than in symmetric fire.

2. Concrete is an effective heat sink for embedded composite columns.

3. It is recommended that heat sink, which increases the axial resistances of columns, be considered in fire design.

4. If a column is embedded in concrete on three sides (fire acts on one side), fire resistance time increases 2.7-fold, in the case of two adjacent embedded sides it increases 1.4-fold, and with one embedded side 1.1-fold compared to symmetric fire.

5. The numbers given above are minimum values, i.e. safe values for all considered cases. In many cases increases up to 4.0 (1S) and 2.0 (2S) were obtained.

6. In case of embedding with sandwich panels, the fire resistance time does not increase as much as with concrete embedding. The increase is about the same as in the adiabatic case.

7. Even there, the increases in fire resistance time are large, especially when fire acts on one side only.

8. Slender columns seemed to collapse towards fire, stocky columns finally collapsed away from the fire. It is recommended that two initial bow imperfection directions, away from and towards fire, should be used when determining fire resistance of composite tubular columns in non-symmetric fires.

9. Tests are badly needed to verify the calculations.

CSC Oy deserves special thanks for providing ABAQUS license, computing time and general assistance. The financial support of Seinäjoen Seudun Elinkeinokeskus (SEEK) is also gratefully acknowledged.

\section{References}

1. Espinos A., Romero M., Hospitaler A. Advanced model for predicting the fire response of concrete filled tubular columns. Journal of Constructional Steel Research. 2010. Vol. 66(8-9). Pp. 1030-1046.

2. Ding J., Wang Y.C. Experimental study of structural behavior of steel beam to concrete filled tubular column assemblies with different types of joints. Engineering Structures. 2007. Vol. 29(12). Pp. 3485-3502.

3. Lie T.T. New facility to determine fire resistance of columns. Canadian Journal of Civil Engineering. 1980. Vol. 7(3). Pp. 551-558.

4. Lie T.T., Chabot M. Fire resistance of hollow steel columns filled with carbonate aggregate concrete: test results. NRC-CNRC Internal Rep., No. 573, Ottawa, Canada, 1988.

5. Lie T.T., Caron S.E. Fire resistance of hollow steel columns filled with siliceous aggregate concrete: test results. NRC-CNRC Internal Rep., No. 570, Ottawa, Canada, 1988.

6. Lie T.T., Chabot M. Experimental studies on the fire resistance of hollow steel columns filled with plain concrete. IRC Internal Report No. 611, Ottawa, Canada, 1992.

7. Lie T.T., Stringer D.C. Calculation of the fire resistance of steel hollow structural section columns filled with plain concrete. Canadian Journal of Civil Engineering. 1994. Vol. 21(3). Pp. 382-385.

8. Kodur V.K.R., Lie T.T. Fire performance of concrete-filled hollow steel columns. Journal of Fire Protection Engineering. 1995. Vol. 7(3). Pp. 89-98.

9. Kodur V.K.R. Performance of high strength concrete-filled steel columns exposed to fire. Canadian Journal of Civil Engineering. 1998. Vol. 25(6). Pp. 975-981.

10. Kodur V.K.R. Performance-based fire resistance design of concrete-filled steel columns. Journal of Constructional Steel Research. 1999. Vol. 51(1). Pp. 21-36.

11. Wang Y.C. A simple method for calculating the fire resistance of concrete-filled CHS columns. Journal of Constructional Steel Research. 2000. Vol. 54(3). Pp. 365-386.

12. Han L-H., Fire performance of concrete filled steel tubular beam-columns. Journal of Constructional Steel Research. 2001. Vol. 57(6). Pp. 695-709.

13. Han L.H., Yang Y.F., Xu L. An experimental study and calculation on the fire resistance of concrete-filled SHS and RHS columns 2003. Journal of Constructional Steel Research. 2003. Vol. 59(4). Pp. 427-452.

Heinisuo M., Jokinen T. Tubular composite columns in a non-symmetrical fire 
14. Han L.H., Zhao X.L., Yang Y.F., Feng J.B. Experimental study and calculation of fire resistance of concrete-filled hollow steel columns. Journal of Structural Engineering. 2003. Vol. 129(3). Pp. 346-356.

15. Kodur V.K.R., Sultan M.A. Effect of temperature on thermal properties of high-strength concrete. Journal of Materials in Civil Engineering. 2003. Vol. 15(2). Pp. 101-107.

16. Kodur V.K.R., Wang T.C., Cheng F.P. Predicting the fire resistance behaviour of high strength concrete columns. Cement \& Concrete Composites. 2004. Vol. 26(2). Pp. 141-153.

17. Kodur V.K.R. Achieving fire resistance through steel concrete composite construction. Structures Congress, 05. New York, April 20-24. New York, 2005. Pp. 1-6.

18. Schaumann P., Kodur V.K.R., Bahr O., Fire resistance of high strength concrete filled steel columns. $4^{\text {th }}$ International Workshop Structures in fire (SiF'06). Aveiro, Portugal, 2006. Pp. 837-849.

19. Yin J., Zha X-X., Li L-y. Fire resistance of axially loaded concrete filled steel tube columns. Journal of Constructional Steel Research. 2006. Vol. 62(7). Pp. 723-729.

20. Grandjean G., Grimault J.P., Petit L. Détermination de la durée au feu des profils creux remplis de béton, Rapport Final, Commission des Communautés Européennes, Recherche technique acier. Luxembourg, 1981. (fra)

21. Chabot M., Lie T.T. Experimental studies on the fire resistance of hollow steel columns filled with barreinforced concrete. IRC Internal Report No. 628, Ottawa, Canada, 1992.

22. Lie T.T. Fire resistance of circular steel columns filled with bar-reinforced concrete. Journal of Structural Engineering. 1994. Vol. 120(5). Pp. 1489-1509.

23. Lie T.T., Irwin R.J. Fire resistance of rectangular steel columns filled with bar-reinforced concrete. Journal of Structural Engineering. 1995. Vol. 121(5). Pp. 797-805.

24. Lie T.T., Kodur V.K.R. Fire resistance of steel columns filled with bar-reinforced concrete. Journal of Structural Engineering. 1996. Vol. 122(1). Pp. 30-36.

25. Kodur V.R., Sultan M.A. Structural behaviour of high strength concrete columns exposed to fire. International Symposium on High Performance and Reactive Powder Concrete, Sherbrooke, Quebec, Sept. 1998. Pp. 217-232.

26. CIDECT, Improvement and extension of the simple calculation method for fire resistance of unprotected concrete filled hollow columns. CTICM, CIDECT research project 15Q-12/03. Saint-Remy-les-Chevreuse, France, 2004. 101 p.

27. Johansson M. Composite action and confinement effects in tubular steel-concrete columns. PhD Thesis. Chalmers University of Technology, Sweden, 2002. Нет страниц

28. Nyman S., Virdi K. Fire response of concrete filled hollow steel sections. Proceedings of EUROSTEEL $20116^{\text {th }}$ European Conference on Steel and Composite Structures, ECCS, Brussels, 2011. Pp. 1575-1580.

29. Kodur V.K.R., Lie T.T. Experimental studies on the fire resistance of circular hollow steel columns filled with steel-fiber-reinforced concrete. IRC Internal Report No. 691, Ottawa, Canada, 1995.

30. Kodur V.K.R., Lie T.T. Experimental studies on the fire resistance of square hollow steel columns filled with steel-fiber-reinforced concrete. IRC Internal Report No. 662, Ottawa, Canada, 1996.

31. Kodur V.K.R., Lie T.T. Fire resistance of circular steel columns filled with fiber-reinforced concrete. Journal of Structural Engineering. 1996. Vol. 122(7). Pp. 776-782.

32. Lie T.T., Kodur V.K.R. Thermal and mechanical properties of steel-fiber-reinforced concrete at elevated temperatures. Canadian Journal of Civil Engineering. 1996. Vol. 23(2). Pp. 511-517.

33. Kodur V.K.R. Design Equations for Evaluating Fire Resistance of SFRC-Filled HSS Columns. Journal of Structural Engineering. 1998. Vol. 124(6). Pp. 671-677.

34. Nataraja M.C., Dhang N., Gupta A.P. Stress-strain curves for steel-fiber reinforced concrete under compression. Cement \& Concrete Composites. 1999. Vol. 21(5-6). Pp. 383-390.

35. Campione G., Mindess S., Scibilia N., Zingone G. Strength of hollow circular steel sections filled with fiberreinforced concrete. Canadian Journal of Civil Engineering. 2000. Vol. 27(2). Pp. 364-372.

36. Kodur V. K. R., Cheng F-P., Wang T-C., Sultan M. A., Effect of strength and fiber reinforcement on fire resistance of high-strength concrete columns. Journal of Structural Engineering. 2003. Vol. 129(2). Pp. 253-259.

37. Cheng F-P., Kodur V.K.R., Wang T-C. Stress-Strain Curves for High Strength Concrete at Elevated Temperatures. Journal of Materials in Civil Engineering. 2004. Vol. 16(1). Pp. 84-90.

38. Bisby L.A., Green M.F., Kodur V.K.R. Modeling the behavior of fiber reinforced polymer-confined concrete columns exposed to fire. Journal of Composites for Construction. 2005. Vol. 9(1). Pp. 15-24.

Heinisuo M., Jokinen T. Tubular composite columns in a non-symmetrical fire 
39. Hatzigeorgiou G.D, Beskos D.E. Minimum cost design of fiber-reinforced concrete-filled steel tubular columns. Journal of Constructional Steel Research. 2005. Vol. 61(2). Pp. 167-182.

40. Ramana G.S., Devadas M.P. Experimental behaviour of eccentrically loaded slender circular hollow steel columns in-filled with fiber reinforced concrete. Journal of Constructional Steel Research. 2006. Vol. 62(5). Pp. 513-520.

41. Pires T., Correia A., Rodrigues J. Silva J. CHS and partially encased columns subjected to fire. Proceedings of EUROSTEEL 2011 6th European Conference on Steel and Composite Structures, ECCS, Brussels, 2011. Pp. 1569-1574.

42. Yang H., Liu F., Zhang S. Fire performance of CFST columns in non-uniform fire. Proceedings of EUROSTEEL 2011 6th European Conference on Steel and Composite Structures, ECCS, Brussels, 2011. Pp. 1563-1568.

43. Yang H., Liu F., Gardner L. Performance of concrete-filled RHS columns exposed to fire on 3 sides. Journal of Constructional Steel Research. 2013. Vol. 56. Pp. 1986-2004.

44. Yang H., Liu F., Zhang S., Lv X., Experimental investigation of concrete-filled square hollow section columns subjected to non-uniform exposure. Journal of Constructional Steel Research. 2013. Vol. 48. Pp. 292-312.

45. Tondini N., Hoang V.L., Demonceau J.-F., Franssen J.-M. Experimental and numerical investigation of high-strength steel circular columns subjected to fire. Journal of Constructional Steel Research. 2013. Vol. 80. Pp. 57-81.

46. ABAQUS 6.10/CAE User's Manual, Dassault Systemes, 2010.

47. EN 1994-1-2 - Eurocode 4: Design of composite steel and concrete structures - Part 1-2: Structural fire design, CEN, Brussels, 2010. P. 110.

48. TRY, Betonitäytteisen teräsliittopilarin suunnitteluohje. Helsinki, 2004. (fin)

49. Kivimaa M. Liittopilareiden lämpötilat epäsymmetrisessä palossa. BSc thesis. Seinäjoki University of Applied Sciences, Seinäjoki, 2012. P. 28. (fin)

50. Heinisuo M., Jokinen T., Salminen M., Embedded Tubular Composite Columns in Fire. Proceedings of Nordic Steel Construction Conference 2012. Pp. 743-752.

51. Jokinen T. Seinää vasten olevat liittopilarit tulipalossa. MSc thesis. Tampere University of Technology, Tampere, 2013. P. 66. (fin)

52. EN 10219, Cold formed welded structural hollow sections of non-alloy and fine grain steels, Part 2: Tolerances, dimensions and sectional properties, 2006. P. 37.

53. SFS 1215, Betoniteräkset. Hitsattava kuumavalssattu harjatanko A500HW, Metalliteollisuuden standardoimiskeskus, 1996. P. 6. (fin)

54. Salminen M. Shear Buckling Resistance of Thin Metal Plate at Non-Uniform Elevated Temperatures. Licenciate thesis, Tampere University of Technology, Tampere, 2010.

55. Hong S., Varma A. Analytical modeling of the standard fire behavior of loaded CFT columns. Journal of Constructional Steel Research. 2009. Vol. 65(1). Pp. 54-69.

56. Zeng J., Mäkeläinen P. Finite Element Modelling of Semi-Rigid Composite Joint in a Slim Floor Frame. Proceedings of Nordic Steel Construction Conference 2009. Pp. 335-342.

Markku Heinisuo, Tampere, Finland +3(5804)596-58-26; e-mail: markku.heinisuo@tut.fi

Timo Jokinen, Tampere, Finland +3(5804)596-58-26; e-mail: timo.jokinen@tut.fi

(c) Heinisuo M., Jokinen T., 2014

Heinisuo M., Jokinen T. Tubular composite columns in a non-symmetrical fire 
doi: 10.5862/MCE.49.11

\title{
Асимметричное огневое воздействие на цилиндрические композитные колонны
}

\author{
PhD, профессор M. Хейнисуо \\ Технологический университет Тампере, Тампере, Финляндия \\ +3(5804)596-58-26; эл. почma: markku.heinisuo@tut.fi \\ B.Sc., научный ассистент T. Йокинен \\ Технологический университет Тампере, Тампере, Финляндия \\ +3(5804)596-58-26; эл. почma: timo.jokinen@tut.fi
}

\section{Ключевые слова}

огнестойкость; железобетонные цилиндрические колонны; асимметричное огневое воздействие; метод конечных элементов; Еврокод

\section{Аннотация}

Значительное количество исследований по всему миру было посвящено огневому воздействию на все четыре стороны колонны (симметричное огневое воздействие). Эти исследования использованы для проверки аналитических моделей, использованных в данной работе. В реальных зданиях часто используются встроенные (заделанные) колонны.

Когда огонь по-разному воздействует на разные стороны колонны (асимметричное воздействие), очень сложно предсказать ее поведение. Основные задачи исследования следующие. Сильнее ли огнестойкость при асимметричном воздействии, чем при симметричном? Какова форма потери устойчивости, в направлении огневого воздействия или противоположно ему?

В статье приведены результаты численного анализа 150 стальных колонн, наполненных железобетоном, под асимметричным воздействием огня. По ISO 834, огонь действует постоянно вдоль колонны на одну, две смежные или три стороны. Для оставшихся сторон рассмотрены три варианта заделки: адиабатическая стена, бетонная стена и сэндвич-панель. Модели материалов выполнены на основе Еврокодов, с учетом начальных несовершенств. Базовым вариантом является случай симметричного воздействия.

Когда огонь воздействует на одну, две смежные или три стороны, предел огнестойкости был в среднем в 3.4, 2 и 1.3 раза выше, чем при симметричном воздействии. Бетонная стена - это хороший теплоотвод для колонн. Гибкие колонны обычно изгибаются в направлении огня. Окончательная потеря устойчивости и, соответственно, огнестойкость зависит от направления начального несовершенства изгиба. Необходимо проведение эксперимента для проверки полученных результатов.

\section{Лumepamypa}

1. Espinos A., Romero M., Hospitaler A. Advanced model for predicting the fire response of concrete filled tubular columns // Journal of Constructional Steel Research. 2010. Vol. 66(8-9). Pp. 1030-1046.

2. Ding J., Wang Y.C. Experimental study of structural behavior of steel beam to concrete filled tubular column assemblies with different types of joints // Engineering Structures. 2007. Vol. 29(12). Pp. 34853502.

3. Lie T.T. New facility to determine fire resistance of columns // Canadian Journal of Civil Engineering. 1980. Vol. 7(3). Pp. 551-558.

4. Lie T.T., Chabot M. Fire resistance of hollow steel columns filled with carbonate aggregate concrete: test results // NRC-CNRC Internal Rep., No. 573, Ottawa, Canada, 1988.

5. Lie T.T., Caron S.E. Fire resistance of hollow steel columns filled with siliceous aggregate concrete: test results // NRC-CNRC Internal Rep., No. 570, Ottawa, Canada, 1988.

6. Lie T.T., Chabot M. Experimental studies on the fire resistance of hollow steel columns filled with plain concrete // IRC Internal Report No. 611, Ottawa, Canada, 1992.

7. Lie T.T., Stringer D.C. Calculation of the fire resistance of steel hollow structural section columns filled with plain concrete // Canadian Journal of Civil Engineering. 1994. Vol. 21(3). Pp. 382-385.

8. Kodur V.K.R., Lie T.T. Fire performance of concrete-filled hollow steel columns // Journal of Fire Protection Engineering. 1995. Vol. 7(3). Pp. 89-98.

Хейнисуо М., Йокинен Т. Асимметричное огневое воздействие на цилиндрические композитные колонны 
9. Kodur V.K.R. Performance of high strength concrete-filled steel columns exposed to fire // Canadian Journal of Civil Engineering. 1998. Vol. 25(6). Pp. 975-981.

10. Kodur V.K.R. Performance-based fire resistance design of concrete-filled steel columns // Journal of Constructional Steel Research. 1999. Vol. 51(1). Pp. 21-36.

11. Wang Y.C. A simple method for calculating the fire resistance of concrete-filled CHS columns // Journal of Constructional Steel Research. 2000. Vol. 54(3). Pp. 365-386.

12. Han L-H., Fire performance of concrete filled steel tubular beam-columns // Journal of Constructional Steel Research. 2001. Vol. 57(6). Pp. 695-709.

13. Han L.H., Yang Y.F., Xu L. An experimental study and calculation on the fire resistance of concrete-filled SHS and RHS columns 2003 // Journal of Constructional Steel Research. 2003. Vol. 59(4). Pp. 427-452.

14. Han L.H., Zhao X.L., Yang Y.F., Feng J.B. Experimental study and calculation of fire resistance of concrete-filled hollow steel columns // Journal of Structural Engineering. 2003. Vol. 129(3). Pp. 346-356.

15. Kodur V.K.R., Sultan M.A. Effect of temperature on thermal properties of high-strength concrete // Journal of Materials in Civil Engineering. 2003. Vol. 15(2). Pp. 101-107.

16. Kodur V.K.R., Wang T.C., Cheng F.P. Predicting the fire resistance behaviour of high strength concrete columns // Cement \& Concrete Composites. 2004. Vol. 26(2). Pp. 141-153.

17. Kodur V.K.R. Achieving fire resistance through steel concrete composite construction // Structures Congress,05. New York, April 20-24. New York, 2005. Pp. 1-6.

18. Schaumann P., Kodur V.K.R., Bahr O., Fire resistance of high strength concrete filled steel columns $/ / 4^{\text {th }}$ International Workshop Structures in fire (SiF'06). Aveiro, Portugal, 2006. Pp. 837-849.

19. Yin J., Zha X-X., Li L-y. Fire resistance of axially loaded concrete filled steel tube columns // Journal of Constructional Steel Research. 2006. Vol. 62(7). Pp. 723-729.

20. Grandjean G., Grimault J.P., Petit L. Détermination de la durée au feu des profils creux remplis de béton, Rapport Final, Commission des Communautés Européennes, Recherche technique acier. Luxembourg, 1981. (fra)

21. Chabot M., Lie T.T. Experimental studies on the fire resistance of hollow steel columns filled with barreinforced concrete // IRC Internal Report No. 628, Ottawa, Canada, 1992.

22. Lie T.T. Fire resistance of circular steel columns filled with bar-reinforced concrete // Journal of Structural Engineering. 1994. Vol. 120(5). Pp. 1489-1509.

23. Lie T.T., Irwin R.J. Fire resistance of rectangular steel columns filled with bar-reinforced concrete // Journal of Structural Engineering. 1995. Vol. 121(5). Pp. 797-805.

24. Lie T.T., Kodur V.K.R. Fire resistance of steel columns filled with bar-reinforced concrete // Journal of Structural Engineering. 1996. Vol. 122(1). Pp. 30-36.

25. Kodur V.R., Sultan M.A. Structural behaviour of high strength concrete columns exposed to fire // International Symposium on High Performance and Reactive Powder Concrete, Sherbrooke, Quebec, Sept. 1998. Pp. 217-232.

26. CIDECT, Improvement and extension of the simple calculation method for fire resistance of unprotected concrete filled hollow columns. CTICM, CIDECT research project 15Q-12/03. Saint-Remy-les-Chevreuse, France, 2004. 101 p.

27. Johansson M. Composite action and confinement effects in tubular steel-concrete columns. PhD Thesis. Chalmers University of Technology, Sweden, 2002.

28. Nyman S., Virdi K. Fire response of concrete filled hollow steel sections // Proceedings of EUROSTEEL 2011 6th European Conference on Steel and Composite Structures, ECCS, Brussels, 2011. Pp. 15751580.

29. Kodur V.K.R., Lie T.T. Experimental studies on the fire resistance of circular hollow steel columns filled with steel-fiber-reinforced concrete // IRC Internal Report No. 691, Ottawa, Canada, 1995.

30. Kodur V.K.R., Lie T.T. Experimental studies on the fire resistance of square hollow steel columns filled with steel-fiber-reinforced concrete. IRC Internal Report No. 662, Ottawa, Canada, 1996.

31. Kodur V.K.R., Lie T.T. Fire resistance of circular steel columns filled with fiber-reinforced concrete // Journal of Structural Engineering. 1996. Vol. 122(7). Pp. 776-782.

32. Lie T.T., Kodur V.K.R. Thermal and mechanical properties of steel-fiber-reinforced concrete at elevated temperatures // Canadian Journal of Civil Engineering. 1996. Vol. 23(2). Pp. 511-517.

33. Kodur V.K.R. Design Equations for Evaluating Fire Resistance of SFRC-Filled HSS Columns // Journal of Structural Engineering. 1998. Vol. 124(6). Pp. 671-677.

Хейнисуо М., Йокинен Т. Асимметричное огневое воздействие на цилиндрические композитные колонны 
34. Nataraja M.C., Dhang N., Gupta A.P. Stress-strain curves for steel-fiber reinforced concrete under compression // Cement \& Concrete Composites. 1999. Vol. 21(5-6). Pp. 383-390.

35. Campione G., Mindess S., Scibilia N., Zingone G. Strength of hollow circular steel sections filled with fiberreinforced concrete // Canadian Journal of Civil Engineering. 2000. Vol. 27(2). Pp. 364-372.

36. Kodur V. K. R., Cheng F-P., Wang T-C., Sultan M. A., Effect of strength and fiber reinforcement on fire resistance of high-strength concrete columns // Journal of Structural Engineering. 2003. Vol. 129(2). Pp. 253-259.

37. Cheng F-P., Kodur V.K.R., Wang T-C. Stress-Strain Curves for High Strength Concrete at Elevated Temperatures // Journal of Materials in Civil Engineering. 2004. Vol. 16(1). Pp. 84-90.

38. Bisby L.A., Green M.F., Kodur V.K.R. Modeling the behavior of fiber reinforced polymer-confined concrete columns exposed to fire // Journal of Composites for Construction. 2005. Vol. 9(1). Pp. 15-24.

39. Hatzigeorgiou G.D, Beskos D.E. Minimum cost design of fiber-reinforced concrete-filled steel tubular columns // Journal of Constructional Steel Research. 2005. Vol. 61(2). Pp. 167-182.

40. Ramana G.S., Devadas M.P. Experimental behaviour of eccentrically loaded slender circular hollow steel columns in-filled with fiber reinforced concrete // Journal of Constructional Steel Research. 2006. Vol. 62(5). Pp. 513-520.

41. Pires T., Correia A., Rodrigues J. Silva J. CHS and partially encased columns subjected to fire // Proceedings of EUROSTEEL 2011 6th European Conference on Steel and Composite Structures, ECCS, Brussels, 2011. Pp. 1569-1574.

42. Yang H., Liu F., Zhang S. Fire performance of CFST columns in non-uniform fire // Proceedings of EUROSTEEL $20116^{\text {th }}$ European Conference on Steel and Composite Structures, ECCS, Brussels, 2011. Pp. 1563-1568.

43. Yang H., Liu F., Gardner L. Performance of concrete-filled RHS columns exposed to fire on 3 sides // Journal of Constructional Steel Research. 2013. Vol. 56. Pp. 1986-2004.

44. Yang H., Liu F., Zhang S., Lv X., Experimental investigation of concrete-filled square hollow section columns subjected to non-uniform exposure // Journal of Constructional Steel Research. 2013. Vol. 48. Pp. 292-312.

45. Tondini N., Hoang V.L., Demonceau J.-F., Franssen J.-M. Experimental and numerical investigation of high-strength steel circular columns subjected to fire // Journal of Constructional Steel Research. 2013. Vol. 80. Pp. 57-81.

46. ABAQUS 6.10/CAE User's Manual, Dassault Systemes, 2010.

47. EN 1994-1-2 - Eurocode 4: Design of composite steel and concrete structures - Part 1-2: Structural fire design, CEN, Brussels, 2010. P. 110.

48. TRY, Betonitäytteisen teräsliittopilarin suunnitteluohje. Helsinki, 2004. (fin)

49. Kivimaa M. Liittopilareiden lämpötilat epäsymmetrisessä palossa. BSc thesis. Seinäjoki University of Applied Sciences, Seinäjoki, 2012. P. 28. (fin)

50. Heinisuo M., Jokinen T., Salminen M., Embedded Tubular Composite Columns in Fire // Proceedings of Nordic Steel Construction Conference 2012. Pp. 743-752.

51. Jokinen T. Seinää vasten olevat liittopilarit tulipalossa. MSc thesis. Tampere University of Technology, Tampere, 2013. P. 66. (fin)

52. EN 10219, Cold formed welded structural hollow sections of non-alloy and fine grain steels, Part 2: Tolerances, dimensions and sectional properties, 2006. P. 37.

53. SFS 1215, Betoniteräkset. Hitsattava kuumavalssattu harjatanko A500HW, Metalliteollisuuden standardoimiskeskus, 1996. P. 6. (fin)

54. Salminen M. Shear Buckling Resistance of Thin Metal Plate at Non-Uniform Elevated Temperatures. Licenciate thesis, Tampere University of Technology, Tampere, 2010.

55. Hong S., Varma A. Analytical modeling of the standard fire behavior of loaded CFT columns // Journal of Constructional Steel Research. 2009. Vol. 65(1). Pp. 54-69.

56. Zeng J., Mäkeläinen P. Finite Element Modelling of Semi-Rigid Composite Joint in a Slim Floor Frame // Proceedings of Nordic Steel Construction Conference 2009. Pp. 335-342.

Полный текст статьи на английском языке: с. 107-120 